Guest Editorial

\section{Manager Reflects on New Environmental Ethics Program at University of Georgia}

\author{
"Why bother?" a friend asked. Here are five \\ answers.
}

When I entered the Graduate Certificate Program in Environmental Ethics at the University of Georgia in 1983 , it seemed like the perfect way to combine my amateur interest in theology with my professional interest in ecological management. The certificate program is new-I was one of the first cohort of graduates in 1985and broadly interdisciplinary. In addition to core courses in philosophy and ecology, students can choose from graduate offerings in forestry, geography, sociology, economics, law, history, literature, art and environmental design. Faculty, friends and students meet for lunches and seminars, at which an ecologist might explain a conservation project to a sculptor, or argue simultaneously with an economist and a philosopher.

Several of my colleagues have, however, questioned the value of environmental ethics for a manager. "Why bother?" they ask. Can anything so abstract really contribute to field work? Can environmental ethics tell us anything we don't already know, either about public attitudes or about damaged ecosystems? Certainly, ethics is not a substitute for sound science or sociology. Nor can it tell us how to conduct a prescribed burn, apply mulch or build an irrigation system. Environmental ethics can, however, give us a better perspective on our philosophy, perception and valuation of nature, and on the history of western environmental thought. Far too often those of us interested in management embrace technology and science without pondering their full social and cultural impacts. Yet an understanding of these matters can have a profound influence on our work.

A first benefit of my own study was an expanded knowledge of the theology of nature. James Watt was "streamlining" the Department of the Interior when I started the program, occasionally justifying his actions by reference to his Christian beliefs. I reviewed the relevant theological writings on creation and compared the opinions of professional theologians with Watt's published statements. Watt suggested rabid environmentalists and government regulations were the root causes of our environmental problems. The Biblical scholars thought the root cause was sin. The exercise produced a published paper and hours of discussion on Christian versus utilitarian viewpoints.

More recently, I have plunged into the question of Christian attitudes toward wilderness. Many Christians haven't thought about prophetic traditions of use of wild or isolated sites for rest, prayer, fasting and encounter with God. When teaching environmental ethics to undergraduate students from Christian colleges at AuSable Institute of Environmental Studies in Michigan, I have begun to experiment with a "prayer notebook" that requires spiritual activities outdoors. This exercise is not only popular with the students because of the insight it provides into their own spiritual practice, but it increases their appreciation of natural settings.

A second benefit of the study program was an exposure to ideas I had little previous contact with or had not taken seriously. One of the more important, since I deal with overgrazing and feral animal problems, was "animal rights." Having grown up on a farm, I had previously dismissed this whole issue as something taken seriously only by elderly women who like to dress their wellgroomed dogs in bow ties and trousers. Careful study of the rights of individuals under our Anglo-Saxon legal system, however, helped me to see the relationship between animal rights, the rights of natural objects (in the sense of Christopher Stone), our cultural values, and our judicial priorities. I also have gained a better understanding of the historic development of some of the humane and animal-protection organizations. I still find it difficult to agree that animal rights is the next logical step after women's rights and legal protection of minors, but I do concede that the vocabulary of "rights" is useful in discussing our treatment of the natural world. In a recent study of values in national park management, I recognized that native species have "rights" under most parkenabling legislation, whereas natural processes, such as fire, usually do not.

A third benefit of the program was gaining an awareness of the historic roots of modern attitudes towards nature. We discussed not only Muir and Leopold, but went back to the Middle Ages and before. Francis Bacon suddenly seemed more relevant to my own life and work than he had when I was in high school. Trends in landscape painting and literature, I found, had been important influences, not only on the attitudes of Americans generally, but on specific trends, such as the national parks movement. I still misspell "transcendentalism," (sic) but when I am working on historic landscape restoration I now try to grasp what the former residents of the site must have thought of the land and its features. Did the colonial settler in the southeast see the forest only as an impediment, perhaps little damaged by the human-ignited fire, or did he or she appreciate the forest for its economic and esthetic value?

My heightened awareness of the ways American values have changed in the past has led to a fourth benefit, a conscious analysis of our present values in landscape management. I have begun to think more critically about possible hazards in our present emphasis on ecosystem management in national parks and nature reserves. We've made mistakes in the past that had to do with our concepts of "good" and "bad." Government hunters once re- 


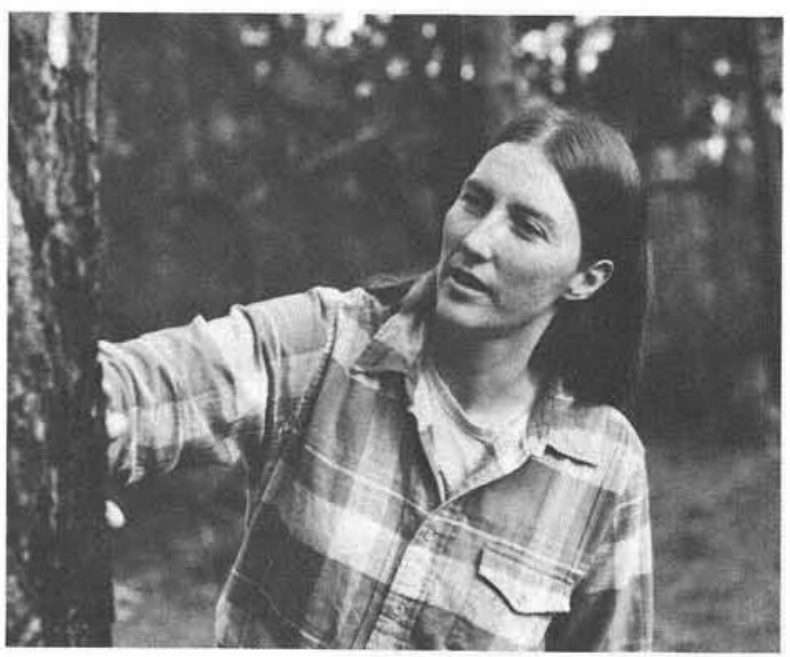

Sue Bratton

moved wolves and mountain lions from Yellowstone and Grand Canyon National Parks. Ambitious fire crews, spurred on by Smokey the Bear, extinguished naturally occurring blazes. Now we are trying to save large predators from extinction in the parks, and we preach prescribed fire from one coast to the other. Do we have similar "bad" objects or processes today that we might change our minds about? In basing decisions on ecosystem models, for example, are we emphasizing the mechanical over the esthetic? Will our fire models encourage us to manipulate natural ecosystems more than we need to? Will "good" processes become those we can control? Do we at times manage systems for uniformity rather than variety?

A last benefit of my study of environmental ethics has been increased communication with people who have little background in science. It is exciting to speak to a group of liberal arts students, some of whom are history or English majors, and to discuss, not just our practical problems in land management, but also the historic roots of our present systems of land use and our attitudes towards land care. An invitation to talk about wilderness in a class on New Testament writings presents a special challenge. So does a phone call from a drama major who wants to discuss environmental perceptions in the history of the theater.

In summary, environmental ethics encourages us to think about why we do things - and that's healthy, even for the experienced land manager or ecologist. Scholars from other disciplines are scrutinizing our values, asking us questions about why something is right or wrong or whether something has intrinsic worth. Responding to this, we go beyond the routine, circular, scientific justifications for what we are doing and confront the views of our time and even our entire cultural heritage. Ethics is the discussion of what we ought to do, which is fundamental to our answers to questions about burn schedules or habitat preservation. It is easy to assume this work has already been done - to take our ideas for granted, accepting them uncritically. It is a weakness of ecological managers that we assume that our longing to protect the environment will always lead us into right action, regardless of the technical, social or legal basis for our decisions.

Susan P. Bratton

Dr. Bratton is a research associate at the Institute of Ecology, University of Georgia, Athens, GA 30602, (404) 542-2968.

\section{To the Editor}

Mr. R.D. Henry's recent letter about the inclusion of alien species in natural areas (R\&MN 3:2) was most intriguing, and I feel compelled to make some response.

Defining plant species as "natural" or "alien" is not always a simple or straightforward thing to do, and the process deserves careful consideration from all restorationists. Mr. Henry notes that one solution to this problem might be a more specific definition of what a natural area is. I like that because it tends to make one think about the role of humans and their effects on plant communities. It seems appropriate to ask whether we as a species are natural. The answer, in my mind, must be yes; and if that is so, what is so unnatural about plant species either intentionally or accidentally relocated by us?

Making the assumption that all plants successfully relocated by humans are natural can greatly change our perspective of the so-called natural and alien species. It also simplifies the matter of defining plant community composition. If a particular species is growing and reproducing successfully at any specific time, regardless of how it got there it can be accepted as a member of the plant community, and should be included as a part of a restoration or management effort.

There is an important and relevant tangent to all this. If species that have been naturalized extirpate species previously viable in the community, then the overall level of diversity may decline. Consequently, restorationists often believe that many species in moderation are better than fewer species in abundance, and their objective in restoring plant communities becomes one of creating (recreating?) diversity. That in turn often means striving for the pre-European settlement species composition, since many of the species naturalized since settlement are aggressive and lead to generally reduced levels of diversity.

Ron Bowen

Mr. Bowen is a member of the editorial board of R\&MN. $\mathrm{He}$ can be reached at Prairie Restorations, Inc., Box 327 , Princeton, MN 55371. (612) 389-4342. 